University of Wollongong

Research Online

Faculty of Engineering and Information

Faculty of Engineering and Information

Sciences - Papers: Part A

Sciences

$1-1-2016$

\title{
Biosolids reduction by the oxic-settling-anoxic process: impact of sludge interchange rate
}

\author{
Galilee U. Semblante \\ University of Wollongong, gus193@uowmail.edu.au \\ Faisal I. Hai \\ University of Wollongong, faisal@uow.edu.au \\ Heriberto A. Bustamante \\ Sydney Water, Parramatta, heri.bustamante@sydneywater.com.au \\ Nelly Guevara \\ Sydney Water, Parramatta \\ William E. Price \\ University of Wollongong, wprice@uow.edu.au
}

See next page for additional authors

Follow this and additional works at: https://ro.uow.edu.au/eispapers

Part of the Engineering Commons, and the Science and Technology Studies Commons

Research Online is the open access institutional repository for the University of Wollongong. For further information contact the UOW Library: research-pubs@uow.edu.au 


\title{
Biosolids reduction by the oxic-settling-anoxic process: impact of sludge interchange rate
}

\begin{abstract}
The impact of sludge interchange rate (SIR) on sludge reduction by oxic-settling-anoxic (OSA) process was investigated. The sludge yield of an OSA system (a sequencing batch reactor, SBR, integrated with external anoxic reactors) was compared to that of a control (an SBR attached to a single-pass aerobic digester). SIR (\%) is the percentage by volume of sludge returned from the external reactor into the main bioreactor of the OSA, and was varied from $0-22 \%$. OSA achieved greater sludge reduction when fed with unsettled sewage $(s C O D=113 \mathrm{mg} / \mathrm{L})$ rather than settled sewage $(\mathrm{sCOD}=60 \mathrm{mg} / \mathrm{L})$. The SIR of $11 \%$ resulted in the highest OSA performance. At the optimum SIR, higher volatile solids destruction and nitrification/denitrification (i.e., conversion of destroyed volatile solids into inert forms) were observed in the external anoxic and intermittently aerated (i.e., aerobic/anoxic) reactors, respectively. Denitrification in the aerobic/anoxic reactor was inefficient without SIR. Effluent quality and sludge settleability were unaffected by SIR.
\end{abstract}

\section{Keywords}

rate, sludge, impact, process, anoxic, settling, oxic, reduction, biosolids, interchange

\section{Disciplines}

Engineering | Science and Technology Studies

\section{Publication Details}

Semblante, G. U., Hai, F. I., Bustamante, H. A., Guevara, N., Price, W. E. \& Nghiem, L. D. (2016). Biosolids reduction by the oxic-settling-anoxic process: impact of sludge interchange rate. Bioresource Technology, $210167-173$.

\section{Authors}

Galilee U. Semblante, Faisal I. Hai, Heriberto A. Bustamante, Nelly Guevara, William E. Price, and Long D. Nghiem 
10

16

$17 *$ Corresponding author:

18 Email: faisal@ uow.edu.au,Ph: +61 242213054

\section{Bioresource Technology}

doi:10.1016/j.biortech.2016.01.010

$$
\text { January } 2016
$$

Galilee U. Semblante ${ }^{\mathrm{a}}$, Faisal I. Hai ${ }^{\mathrm{a} *}$, Heriberto Bustamante ${ }^{\mathrm{b}}$, Nelly Guevara ${ }^{\mathrm{b}}$, William E. Price ${ }^{\mathrm{c}}$, and Long D. Nghiem ${ }^{\mathrm{a}}$

${ }^{a}$ Strategic Water Infrastructure Laboratory, School of Civil, Mining and Environmental Engineering, University of Wollongong, Wollongong, NSW 2522, Australia

${ }^{\mathrm{b}}$ Sydney Water, Parramatta, NSW 2124, Australia

${ }^{c}$ Strategic Water Infrastructure Laboratory, School of Chemistry, University of Wollongong, Wollongong, NSW 2522, Australia

19

20

21

22

23 


\section{Abstract}

25 The impact of sludge interchange rate (SIR) on sludge reduction by oxic-settling-anoxic (OSA)

26 process was investigated. The sludge yield of an OSA system (a sequencing batch reactor, SBR,

27 integrated with external anoxic reactors) was compared to that of a control (an SBR attached to a

28 single-pass aerobic digester). SIR $(\%)$ is the percentage by volume of sludge returned from the

29 external reactor into the main bioreactor of the OSA, and was varied from $0-22 \%$. OSA

30 achieved greater sludge reduction when fed with unsettled sewage ( $\mathrm{sCOD}=113 \mathrm{mg} / \mathrm{L}$ ) rather than

31 settled sewage $(\mathrm{sCOD}=60 \mathrm{mg} / \mathrm{L})$. The SIR of $11 \%$ resulted in the highest OSA performance. At

32 the optimum SIR, higher volatile solids destruction and nitrification/denitrification (i.e.,

33 conversion of destroyed volatile solids into inert forms) were observed in the external anoxic and

34 intermittently aerated (i.e., aerobic/anoxic) reactors, respectively. Denitrification in the

35 aerobic/anoxic reactor was inefficient without SIR. Effluent quality and sludge settleability were

36 unaffected by SIR.

37 Keywords: denitrification, oxic-settling-anoxic, sludge interchange rate, sludge/biosolids

38 reduction.

40 1. Introduction

41 The worldwide trend of increasing environmental standards, particularly in sewer coverage,

42 entails the production of excess sludge, an inevitable by-product of biological wastewater

43 treatment. The EU, the USA, and China each produce 6-11 million tons of sludge as dry solids

44 (DS) per year (Fytili and Zabaniotou, 2008; Semblante et al., 2014; Yang et al., 2015). Australia

45 also produces a significant amount of DS (ca. 0.3 million tons) each year (Semblante et al.,

46 2014). The production of excess sludge is problematic because sludge volume is notoriously 
47 difficult to reduce due to its unique biological properties (Mowla et al., 2013; Ratanatamskul and

48 Saleart, 2015), and there are only a few options for sludge disposal (landfilling, incineration, agricultural reuse) (Tchobanoglus et al., 2003). Landfilling is heavily restricted especially in

50 countries with limited space. Incineration removes only $70 \%$ of DS and creates ash with high

51 metal content (Fytili and Zabaniotou, 2008). The agricultural reuse of stabilised and dewatered

52 sludge called "biosolids" has been encouraged to enable nutrient recycling. However, the transport of biosolids to end users is potentially costly (Semblante et al., 2014). Furthermore,

54 biosolids may contain trace organic compounds, such as pharmaceuticals, pesticides, and

55 industrial chemicals, which have long-term effect on the environment and human health (Clarke and Cummins, 2015; Semblante et al., 2015b). Therefore, to decrease the costs and risks

57 associated with sludge treatment and disposal, it is imperative that sludge production is reduced.

58 Research efforts have generated innovative strategies such as the use of advanced oxidation

59 processes to destroy biomass (Wang et al., 2015; Yao et al., 2008), chemical addition to disrupt

60

metabolic processes (Fang et al., 2015; Feng et al., 2014), and sludge cycling in alternating redox conditions through the oxic-settling-anoxic (OSA) process (Semblante et al., 2014). Although the use of advanced oxidation processes and chemical addition has shown potential to reduce sludge, they require high capital investment (Foladori et al., 2010) and/or may introduce undesired products in treated water (Mahmood and Elliott, 2006). In contrast, OSA offers a potentially cost-efficient and low-impact alternative to sludge reduction.

OSA reduces sludge production by temporarily holding activated sludge in an external anoxic and substrate-deficient reactor, then recirculating it to the main bioreactor. Several mechanisms of sludge reduction in OSA have been hypothesized. They include enhanced cell lysis, extracellular polymeric substance (EPS) degradation, and selection of slow-growing bacteria (Navaratna et al., 2014; Semblante et al., 2014). A few OSA configurations including those that 
71 involve external anaerobic (Chon et al., 2011; Chudoba et al., 1992) or anoxic (Coma et al.,

72 2013; Saby et al., 2003) reactors have been discussed in the literature. Laboratory-scale OSA fed

73 with synthetic wastewater have shown promising sludge reduction (e.g. 50-80\%) (Chon et al.,

74 2011; Saby et al., 2003; Sun et al., 2010). However, these high sludge reduction values have not

75 been realized in full-scale systems (Coma et al., 2013). In a previous study, $30 \%$ reduction in the

76 sludge yield was achieved by a laboratory scale OSA system using real sewage (Semblante et al.,

77 2015a). OSA performance is influenced by different operation conditions, such as oxidation

78 reduction potential (ORP), sludge retention time (SRT), and sludge loading rate of the external

79 reactor (Coma et al., 2013; Saby et al., 2003; Ye et al., 2008). To date, the manipulation of these

80 parameters have only resulted in variable success (Coma et al., 2013; Saby et al., 2003; Ye et al.,

81 2008).

82 To improve OSA performance and ensure reliable performance for the water industry, it is

83 essential to elucidate the impact of operation conditions such as sludge interchange rate (SIR)

84 and influent chemical oxygen demand (COD) on sludge reduction. Changing SIR varies the

85 residence time of sludge in aerobic/anoxic regimes and may have important implications on

86 sludge reduction mechanisms. However, current information in the literature is inadequate to

87 pin-point the optimum SIR value or range for sludge reduction.

88 Khursheed et al. (2015) observed that increasing the ratio of sludge exposed to anaerobic and

89 aerobic conditions (0-8.24 $\left.\mathrm{g} \mathrm{MLVSS}_{\text {anaerobic }} / \mathrm{g} \mathrm{MLVSS}_{\text {aerobic }}\right)$ in OSA enhanced sludge reduction

90 (0-39.8\%). Saby et al. (2003) investigated the impact of sludge retention time (SRT) in the

91 external anoxic reactor of OSA over a range of 11-17 days and observed $23-58 \%$ reduction in

92 biosolids production under longer SRTs or smaller SIRs. The SRT of the anoxic reactor in the

93 study of Saby et al. (2003) was significantly longer than that of Ye et al. (2008) (5.5-11.5 h), but

94 similar sludge reduction has been achieved by both studies. On the other hand, Sun et al. (2010) 
were able to achieve an enhanced sludge reduction (from 53 to $77 \%$ ) by increasing the

96 frequency of return from once per day to four times per day while maintaining the SIR between

97 an SBR and an external anaerobic reactor at 10\%. Given the inconsistent trends reported in the

98 literature, it is worthwhile to systematically investigate the impact of SIR on OSA performance.

99 Additionally, influent COD concentration affects biomass growth and substrate consumption

100 (Gómez et al., 2006), but its impact on OSA remains to be evaluated. Thus, a systematic

101

investigation under different influent COD concentrations is essential to assess the performance

102 of OSA in plants with and without primary sedimentation.

103 To address the aforementioned research gaps, this study aims to systematically investigate the

104 impact of SIR on sludge reduction by OSA at different influent strengths, i.e., using real sewage

105 before and after primary settling. Volatile solids content and a range of water quality parameters

106 including COD and nutrient concentrations of the reactors were monitored during continuous

107 operation of the reactors over a period of 475 days to elucidate the impact of SIR on sludge

108 reduction.

109 2. Materials and methods

110

2.1 Wastewater characteristics

111 Unsettled and settled sewage (Table 1) were collected from the Wollongong WWTP fortnightly

112 and stored at $4{ }^{\circ} \mathrm{C}$. The former was collected at the beginning while the latter was collected at the

113 outlet of the sedimentation channel. It is noted that due to rapid hydrolysis of readily

114 biodegradable solid particles and the higher soluble ammonia concentration in the unsettled

115 sewage, the soluble COD (sCOD) of the unsettled sewage was significantly higher than that of

116 the settled sewage $(113 \pm 87, \mathrm{n}=33$ vs. $60 \pm 32, \mathrm{n}=48)$ as can be seen in Table 1 .

[Table 1] 
119 Two systems were operated in parallel: the first consists of $\mathrm{SBR}_{\text {control }}(5 \mathrm{~L})$ attached to a single-

120 pass aerobic digester (2 L) forming the control system (Figure 1a), and the second consists of

$121 \operatorname{SBR}_{\text {OSA }}(5 \mathrm{~L})$ attached to a sequential aerobic/anoxic reactor $(2 \mathrm{~L})$ and anoxic reactor $(2 \mathrm{~L})$ to

122 form the OSA system (Figure 1b).

[Figure 1]

$124 \mathrm{SBR}_{\text {control }}$ and SBR $\mathrm{OSA}$ were fed with real wastewater (Section 2.1), and operated at 4 cycles/day 125 and a HRT of 12 hours. Each cycle comprised of 15 min of filling, 5 hours and $30 \mathrm{~min}$ of aeration, 1 hour of settling, and 15 min of decanting. The SRT of both SBRs was maintained at

12710 days by regular sludge wastage (W) (Figure 1).

128 The aerobic digester of the control system (Figure 1a) was continuously aerated using an air 129 diffuser. The SRT of this digester was maintained at 20 days by regular sludge wastage ( $\left.\mathrm{Q}_{\text {out }}\right)$.

130 The aerobic digester was fed with sludge from $\mathrm{SBR}_{\text {control }}$ thickened to $5-10 \mathrm{~g} / \mathrm{L}$ by centrifugation 131 for $10 \mathrm{~min}$ at $3,267 \mathrm{xg}\left(\mathrm{Q}_{\text {in }}\right)$. The supernatant produced by the thickening step was discarded.

132 In the OSA system (Figure 1b), the aerobic/anoxic reactor was intermittently aerated (i.e., 8/16

133 hours aeration on/off) using an air diffuser placed at the bottom of the reactor, while the anoxic 134 reactor was kept airtight using a silicone-lined cap with inlet and outlet ports. The aerobic/anoxic 135 reactor was fed with sludge from $\mathrm{SBR}_{\mathrm{OSA}}$ thickened to 5-10 $\mathrm{g} / \mathrm{L}\left(\mathrm{q}_{1}\right)$.

136 Thirty-three percent (33\%) of sludge from the aerobic/anoxic reactor was transferred to the 137 anoxic reactor $\left(\mathrm{q}_{2}\right)$, and $67 \%$ was discharged to achieve a total SRT of 20 days $\left(\mathrm{q}_{3}\right)$. The sludge 138 discharged from the aerobic/anoxic reactor was thickened to $16-24 \mathrm{~g} / \mathrm{L}$ by centrifugation for 10 $139 \min$ at $3,267 \mathrm{xg}$. The supernatant was returned to $\mathrm{SBR}_{\mathrm{OSA}}$, and the pellet was discarded. Sludge 140 from the anoxic reactor was returned to the aerobic/anoxic reactor $\left(\mathrm{q}_{4}\right)$ and $\mathrm{SBR}_{\mathrm{OSA}}\left(\mathrm{q}_{5}\right)$.

141 The control and OSA systems were initially operated for 151 days using settled sewage as feed, 142 during which steady-state was achieved. Then, to observe the impact of SIR on OSA 
143 performance, the SIR between the anoxic reactor and $\mathrm{SBR}_{\mathrm{OSA}}\left(\mathrm{q}_{5}\right)$ was adjusted to $11,16.5$, and $14422 \%$ by volume (Figure $1 \mathrm{~b}$ ) while using settled sewage as fed to the SBRs (Supplementary Table 145 S1). The best OSA performance, i.e., the highest reduction in sludge yield of SBR OSA $_{\text {relative to }}$ $146 \mathrm{SBR}_{\text {control }}$ was achieved at $11 \%$, and thus this condition was also evaluated using unsettled 147 sewage as feed to the SBRs (Section 3.2). To confirm the observed trends with unsettled sewage, 148 the interchange of sludge between $\mathrm{SBR}_{\mathrm{OSA}}$ and the external anoxic reactor was suspended (i.e., 149 there was no SIR), and then resumed at 11\% (Supplementary Table S1).

$150 \quad 2.3$ Calculation of sludge yield

151 Sludge reduction was determined by comparing the sludge yield of the SBRs. The observed 152 sludge yield $\left(Y_{o b s}\right)$ was defined as:

153

$$
Y_{o b s}=\frac{P}{C}=\frac{g M L V S S}{g s C O D}
$$

Equation 1

wherein $P$ is the sludge produced in terms of mixed liquor volatile suspended solids (MLVSS) 156 and $C$ is the substrate consumed in terms of sCOD. The experimental $Y_{o b s}$ was derived from the 157 slope of the linear regression of the cumulative sludge produced versus the cumulative substrate 158 consumed (Supplementary Table S2). Cumulative values were obtained by incrementing the 159 variations in sludge production and substrate consumption in previous sampling intervals (Chon 160 et al., 2011).

161

162 The reduction in sludge yield due to OSA was estimated using Equation 2: 
Sludge yield reduction (\%)

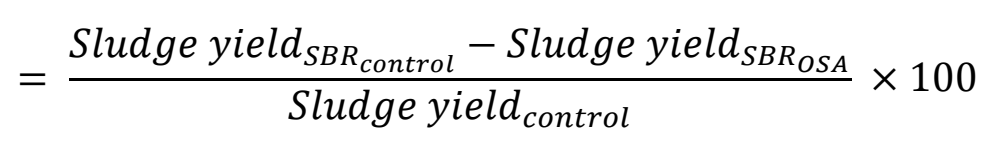

Equation 2

164

165

166

167

168

169

170

171

172

173

174

175

176 177 exchange column.

178

179

180

181

182

183

184

185

79

\subsection{Analytical techniques}

Total and volatile suspended solids (TSS and VSS) of influent and effluent and MLSS and MLVSS of sludge were measured using the APHA Standard Method 2540 (Eaton et al., 2005). The sludge volume index (SVI) was measured using $1000 \mathrm{~mL}$ of sludge according to APHA Standard Method 2710-D (Eaton et al., 2005). The sCOD of influent and effluent was measured by passing samples through $1 \mu \mathrm{m}$ filter paper followed by measurement using a Hach DBR200 COD Reactor and a Hach DR/2000 spectrophotometer (program number 430 COD LR) according to US-EPA Standard Method 5220. Total organic carbon (TOC) and total nitrogen (TN) were analyzed using a TOC/TN-VCSH analyzer (Shimadzu, Japan). Ammonia $\left(\mathrm{NH}_{3}\right)$ and orthophosphate $\left(\mathrm{PO}_{4}{ }^{3-}\right)$ were measured using flow injection analysis (Lachat instruments, Milwaukee, USA) following the APHA Standard Method 4500 (Eaton et al., 2005). Nitrite and nitrate were measured using ion chromatography (Shimadzu, Japan) with Ionpac AS23 anion-

\section{Results and discussion}

\subsection{Impact of sludge interchange rate}

\subsubsection{Reactor performance}

OSA performance was initially investigated using low strength (settled) sewage (Supplementary

Table S1). During this period, the TOC removal efficiency of $\mathrm{SBR}_{\text {control }}(58.4 \pm 31.1 \% ; \mathrm{n}=48)$ and 
186

187

188

189

190

191

192

193

194

195

196

197

effluent quality of $\mathrm{SBR}_{\text {control }}$ and $\mathrm{SBR}_{\mathrm{OSA}}$ were similar to each other in terms of COD and ammonia concentration (Figure 2). The results indicate that the effluent quality from the main bioreactor (i.e., $\mathrm{SBR}_{\mathrm{OSA}}$ ) was unaffected by any variation in SIR.

[Figure 2]

$\mathrm{SBR}_{\text {control }}$ and $\mathrm{SBR}_{\mathrm{OSA}}$ did not exhibit any discernible orthophosphate removal. The amount of anoxic sludge (orthophosphate concentration $=48.4 \pm 23.0 \mathrm{mg} / \mathrm{L} ; \mathrm{n}=22$ ) interchanged with $\mathrm{SBR}_{\mathrm{OSA}}$ was relatively low (0.033-0.067 L/day), therefore such interchange did not affect orthophosphate removal by SBR ${ }_{\text {OSA }}$. The SVI of $\mathrm{SBR}_{\text {control }}$ and $\mathrm{SBR}_{\mathrm{OSA}}$ at all SIR was below $100 \mathrm{~mL} / \mathrm{g}$ (Supplementary Figure S4), confirming that SIR had negligible impact on sludge settleability.

\subsubsection{Sludge reduction}

Discernible variation in MLVSS of $\mathrm{SBR}_{\text {control }}$ and $\mathrm{SBR}_{\mathrm{OSA}}$ occurred due to temporal fluctuations in the sCOD of the settled sewage (Figure 3). Nonetheless, SBR $_{\text {control }}$ maintained a slightly lower MLVSS than that of SBR OSA when SIR was 16.5 and $22 \%$. The opposite occurred when SIR was changed to $11 \%$ (Figure 3). This is an indication that sludge reduction by SBR OSA was enhanced at an SIR of $11 \%$, and the sludge yield data (Table 2) further demonstrated this trend.

\section{[Figure 3]}

\section{[Table 2]}

An SIR of 11, 16.5, and $22 \%$ was equivalent to a residence time of 17.2, 16, and 15 days, respectively, in the external reactors. Comparison of the sludge yield ( $\left.\mathrm{Y}_{\mathrm{obs}}\right)$ of $\mathrm{SBR}_{\text {control }}$ and $\mathrm{SBR}_{\mathrm{OSA}}$ (Supplementary Figure S5) shows that the highest sludge yield reduction (i.e., 53\%) was attained at an SIR of $11 \%$ (Table 2). Although a systematic investigation of SIR is not available in the literature, the findings of this study agree with the general trend reported in a few available studies. Saby et al. (2003) and Coma et al. (2013) have suggested that longer treatment of sludge 
under substrate- and oxygen-deficient conditions may lead to higher sludge reduction in OSA.

210 However, they did not investigate the processes and reactions that were impacted by residence

211 time. These are critically discussed in Section 3.3.

212 Sun et al. (2010) achieved a 30\% enhancement in sludge reduction by increasing the sludge

213 exchange frequency, while maintaining an SIR of 10\%. The mechanism behind this trend was

214 not elucidated. Nevertheless, it is possible that faster degradation of the returned sCOD occurred

215 in the SBR at higher return rate (Sun et al., 2010). Further investigation of the combined effect of

216 SIR and sludge interchange frequency is recommended, but that is beyond the scope of this

217 study.

$218 \quad 3.2$ Impact of wastewater strength

219 3.2.1 Reactor performance

220 OSA performance was further investigated at higher feed sCOD by changing the feed provided

221 to the SBRs from settled (sCOD $=60 \pm 32 \mathrm{mg} / \mathrm{L} ; \mathrm{n}=48$ ) to unsettled sewage (sCOD $=113 \pm 32$

$222 \mathrm{mg} / \mathrm{L} ; \mathrm{n}=32$ ) (Table 1 and Section 2.1). During this period, the OSA was operated at an SIR of

$22311 \%$ and without SIR (Supplementary Table S1). Changing the feed did not impact the

224 wastewater treatment performance of the SBRs in that the effluent TOC, sCOD and ammonia

225 concentrations of $\mathrm{SBR}_{\text {control }}$ and $\mathrm{SBR}_{\mathrm{OSA}}$ were comparable (Figure 2 and Supplementary Figure

226 S3) at both regimes. However, as noted in Section 3.2.2, this had implications on the extent of

227 sludge yield reductions achieved.

228

229 3.2.2 Sludge reduction

230 The sludge yield of both $\mathrm{SBR}_{\text {control }}$ and $\mathrm{SBR}_{\mathrm{OSA}}$ decreased when feed was changed from settled

231 to unsettled sewage (Table 2). This is probably a response of microorganisms to the sudden

232 change in wastewater characteristics (SCOD and composition). Nonetheless, at SIR of $11 \%$, the 
233 sludge yield of $\mathrm{SBR}_{\mathrm{OSA}}$ decreased further to nearly zero and therefore the calculated sludge

234 reduction was $100 \%$ (Table 2). This result suggests that OSA is most effective for treatment

235 plants being fed with relatively high strength (e.g., unsettled) sewage.

236 Higher influent sCOD concentration significantly increased the MLVSS/MLSS ratio of SBR OSA $_{1}$

237 from $0.53 \pm 0.10(\mathrm{n}=43)$ to $0.66 \pm 0.11(\mathrm{n}=33)$ (two sample $t$-test; $t(65)=4.15, p=1.99, \alpha=0.05)$.

238 There is minimal study on the effect of MLVSS loading on OSA external reactors. However, a

239 previous study also showed that higher MLVSS loading on the external reactors can reduce the

240 MLVSS of the waste activated sludge (Semblante et al., 2015a). Higher MLVSS loading has

241 been also reported to improve the performance of anaerobic digesters possibly by influencing the

242 activity of hydrolysing bacterial groups (Mao et al., 2015).

243 To determine the performance of OSA at an SIR approaching zero, the interchange of sludge

244 between $\mathrm{SBR}_{\mathrm{OSA}}$ and external reactors was stopped (i.e., there was no SIR). At this stage,

$245 \mathrm{SBR}_{\text {control }}$ and $\mathrm{SBR}_{\mathrm{OSA}}$ were essentially under the same operation conditions, and therefore they

246 eventually exhibited a similar sludge yield (Table 2).

247 To determine the repeatability of the findings, SIR was resumed at $11 \%$ with unsettled sewage

248 (Day 442-475). Sludge yield reduction by SBR OSA was again evident, but it was lower than that

249 achieved in the previous trial (Day 347-400). However, this can be attributed to the fact that

250 sCOD concentration of unsettled sewage during Day 442-475 $(74 \pm 36 \mathrm{mg} / \mathrm{L} ; \mathrm{n}=8)$ was

251 significantly lower compared to that at earlier periods ( $128 \pm 96 \mathrm{mg} / \mathrm{L} ; \mathrm{n}=24)$, which reaffirms our

252 recommendation of feeding higher strength sewage to OSA plants.

253 Unlike the anecdotal use of an SIR of around 10\% in the previous studies (Chon et al., 2011;

254 Novak et al., 2007), this study systematically studied the impact of SIR over a range of $0-22 \%$

255 and showed the greatest sludge yield reduction at an SIR of $11 \%$. This study furthermore

256 demonstrates that the sludge yield reduction can only be ascertained as a range (e.g., between 30 
257 and $100 \%$ sludge reduction) depending on wastewater strength, and the beneficial effect of OSA

258 is derived better at higher feed strength as it leads to greater amount of volatile solids undergoing

259 treatment in the external reactors.

260 Endogenous MLVSS production may occur in the aerobic digester and aerobic/anoxic and 261 anoxic reactors when biomass consumes products of cell lysis (Hao et al., 2010). Therefore, the 262 sludge yield of the control (combined $\mathrm{SBR}_{\text {control }}$ and aerobic digester) and OSA (combined $263 \mathrm{SBR}_{\mathrm{OSA}}$ and external aerobic/anoxic and anoxic reactors) systems were also calculated

264 (Supplementary Table S6). Similarly, the greatest sludge reduction was observed at SIR of $11 \%$ 265 with either settled or unsettled sewage.

\subsection{Analysis of sludge reduction mechanisms}

268 To understand the impact of SIR on the sludge reduction mechanism of OSA, the volatile solids, 269 organic, and nutrient concentrations in the aerobic/anoxic and anoxic reactors were analysed.

270 Results show that an intermediate SIR (11\%) promoted (a) volatile solids destruction in the

271 anoxic reactor (evident in the release of ammonia and phosphate) and (b)

272 nitrification/denitrification in the aerobic/anoxic reactor. This process ensures that destroyed 273 volatile solids are converted into inert products.

\subsubsection{Settled sewage}

276 The external anoxic reactor was responsible for volatile solids destruction in OSA. The

277 MLVSS/MLSS ratio of the external anoxic reactor $(0.45 \pm 0.13, \mathrm{n}=37)$ was generally lower than 278 that of the aerobic/anoxic reactor $(0.51 \pm 0.10, \mathrm{n}=37)$ and $\operatorname{SBR}_{\mathrm{OSA}}(0.52 \pm 0.10, \mathrm{n}=37)$ when settled 279 sewage was used as the feed (Figure 4). Volatile solids destruction was indicative of cell lysis. 280 Saby et al. (2003) noted that cell lysis in OSA was greater when the external reactor was anoxic 
$281(\mathrm{ORP}<-150 \mathrm{mV})$ than when it was aerobic $(\mathrm{ORP}=100 \mathrm{mV})$. In this study, volatile solids

282 destruction at lower SIR was corroborated by the increase of orthophosphate concentration in the

283 sludge supernatant. The increase in orthophosphate, a product of cell lysis, has also been

284 observed or expected in OSA external reactors in previous studies (Goel and Noguera, 2006;

285 Saby et al., 2003). Here, orthophosphate concentration in the external anoxic reactor was 1.75

286 times higher at the SIR of $11 \%(52.9 \pm 21.5 \mathrm{mg} / \mathrm{L} ; \mathrm{n}=16)$ than at $22 \%(30.1 \pm 2.2 \mathrm{mg} / \mathrm{L} ; \mathrm{n}=4)$

287 (Figure 5). Notably, volatile solids destruction and the increase in orthophosphate concentration

288 was more evident when the MLVSS loading to the external reactors was high (i.e., when the

289 MLVSS/MLSS ratio of SBR $_{\mathrm{OSA}}$ increased as a result of feeding unsettled sewage), and therefore

290 discussed in more detail in Section 3.3.2.

291

[Figure 4]

292

[Figure 5]

293 In addition to volatile solids destruction in the external anoxic reactor, results also revealed the

294 occurrence of nitrification/denitrification in the external aerobic/anoxic reactor. It has been

295 hypothesized that OSA reduces sludge by selecting certain enriched bacteria that readily

296 consumes the biodegradable products of cell lysis. These bacteria convert lysed materials into

297 inert forms (e.g., $\mathrm{H}_{2} \mathrm{O}, \mathrm{CO}_{2}$, and $\mathrm{N}_{2}$ ) and consequently decrease organic load during a continuous

298 cycle of sludge interchange (Semblante et al., 2014). According to Zhou et al. (2014), these

299 bacteria possibly include slow-growing nitrifiers (e.g., Nitrospira), which are enriched in OSA.

300 In the current study, a relationship between SIR and nitrification has been observed: a net

301 increase of ammonia occurred in the aerobic/anoxic reactor when SIR was $22 \%$ but not when it

302 was $11 \%$ (Figure 5), indicating that the former condition did not favour nitrification. The low

303 residence time of sludge (15 days) in the external aerobic/anoxic reactor at the SIR of $22 \%$ could

304 be responsible for the lack of ammonia removal. Nitrification is generally improved by longer 
sludge residence time. For instance, $\mathrm{Li}$ and $\mathrm{Wu}$ (2014) found that nitrifiers were enriched in

306 SBRs when SRT was increased from 5-40 days. Likewise, Chuang et al. (1997) found that

307 increasing SRT from 10 to 15 days enhanced ammonia removal in an activated sludge-biofilm

308 reactor. More significant removal of ammonia in the external aerobic/anoxic reactor (62-74\%)

309 was observed when feed was unsettled sewage, and this is discussed in greater detail in Section

$310 \quad 3.3 .2$.

311 The SIR of $11 \%$ and $22 \%$ both resulted in an accumulation of nitrate in the aerobic/anoxic

312 reactor, indicating poor denitrification. This was due to insufficient COD. The theoretical

$313 \mathrm{COD} / \mathrm{N}$ ratio for biological denitrification is 3.74 (Chiu and Chung, 2003), but the actual COD/N

314 loading ratio into the aerobic/anoxic reactor during this period (i.e., when feed was settled

315 sewage) was 1.49-1.70 only. The enhancement of denitrification efficiency at the SIR of $11 \%$

316 was clearly observed when the feed was unsettled sewage (Section 3.3.2).

\subsubsection{Unsettled sewage}

319 Similar to the observation when feed was settled sewage (Section 3.3.1), the average

MLVSS/MLSS ratio of the external anoxic reactor was lower than that of the aerobic/anoxic

321 reactor and $\mathrm{SBR}_{\mathrm{OSA}}$ (Figure 4). This low MLVSS/MLSS ratio suggests that the external anoxic

322 reactor was primarily responsible for volatile solids destruction in the OSA system. Furthermore,

323 the levels of orthophosphate and ammonia in the external anoxic reactor increased by 1.5 times

324 and 7-10 times, respectively (Figure 5). Notably, nutrients accumulated in the external anoxic

325 reactor (Figure 5), but not COD (Supplementary Figure S7). This was because the COD released

326 by volatile solids destruction was consumed during denitrification reaction. The findings here are

327 different from that of Saby et al. (2003), which observed an accumulation of COD in the external 
328

329

330

331

332

333

334

335

336

337

338

339

340

341

342

343

344

345

346

347

348

349

350

351

anoxic reactor. This is probably because the additional aerobic/anoxic reactor used in this study enriched denitrifying organisms, which consumed nitrate and COD (Figure 5).

The highest removals of ammonia (62-74\%) and nitrate (17-21\%) in the external aerobic/anoxic reactor were observed when SIR was $11 \%$ and the feed was unsettled sewage. In contrast, no removal but rather an accumulation of ammonia and nitrate occurred when SIR was $22 \%$ (Section 3.3.1). This confirms that lower SIR increased the residence time of sludge in the external aerobic/anoxic reactor and facilitated nitrification/denitrification (Ye et al., 2008), consequently converting by-products of volatile solids destruction into inert species (Semblante et al., 2014).

When low strength (settled) sewage was used as the feed, denitrification in the external aerobic/anoxic reactor was negligible at an SIR of $11 \%$ probably because of low COD/N loading ratio in the reactor (Section 3.3.1). The COD/N loading ratio during the experimental run with unsettled sludge (1.73-2.24) was higher than that of the previous run (1.49-1.70) due to lower nitrate concentration in the feed sludge (Figure 5). The increased availability of COD potentially contributed to the enhancement of denitrification in the aerobic/anoxic reactor during this period.

\subsection{Role of sludge interchange in OSA}

In the absence of SIR, there was no influence of the external reactors on the main bioreactor, and, hence, no sludge reduction in $\mathrm{SBR}_{\mathrm{OSA}}$. On the other hand, suspending the recirculation of sludge between $\mathrm{SBR}_{\mathrm{OSA}}$ and the external reactors had minimal effect on volatile solids reduction in the external anoxic reactor (Figure 4) and nitrification in the aerobic/anoxic reactor (Figure 5). However, during this period, the concentration of nitrite increased by 5-10 times in the 
352 aerobic/anoxic and anoxic reactors (Figure 5), which, according to Cortez et al. (Cortez et al.,

353 2009), can be taken as an indicator of inefficient denitrification. This decline in denitrification

354 efficiency in the external aerobic/anoxic reactor was possibly due to insufficient COD in absence

355 of sludge interchange.

357 The relevance of interchanging sludge in the OSA process is further emphasized when OSA

358 performance is compared with single-pass aerobic or anaerobic digesters. The MLVSS/MLSS

359 ratio of the control aerobic digester $(0.55 \pm 0.08, n=37$ and $0.68 \pm 0.08, n=31$ when feed was settled

360 and unsettled sewage, respectively) was slightly higher than that of $\operatorname{SBR}_{\text {control }}(0.52 \pm 0.22, \mathrm{n}=37$

361 and $0.69 \pm 0.22, n=31$ when feed was settled and unsettled sewage, respectively), indicating that

362 aerobic digestion was unable to induce significant volatile solids destruction (Supplementary

363 Figure S8). Furthermore, when the circulation between $\mathrm{SBR}_{\mathrm{OSA}}$ and the external reactors were

364 disconnected (i.e., when there was no SIR and the external reactors virtually functioned as

365 single-pass digesters), the sludge yield of $\mathrm{SBR}_{\mathrm{OSA}}$ became comparable to that of $\mathrm{SBR}_{\text {control. The }}$

366 results of this study reinforce previous findings demonstrating that SBRs in OSA systems have

367 lower sludge yield than SBRs attached to single-pass aerobic or anaerobic digesters (Chon et al.,

368 2011; Ye et al., 2008). This suggests that in the absence of sludge interchange between the main

369 bioreactor and external reactors, the mechanism responsible of reducing sludge yield in the main 370 bioreactor is switched off.

372 4. Conclusion

373 An intermediate SIR (11\%) increased sludge residence time in the external reactors and

374 maximized OSA performance through two mechanisms: (a) providing optimum environment for

375 volatile solids destruction as evidenced by the increase in orthophosphate under anoxic 
conditions; (b) facilitating the conversion of lysed materials into inert forms as evidenced by the decrease in ammonia and nitrate under aerobic/anoxic conditions. SIRs over $11 \%$ showed lower OSA performance, whereas without SIR sludge reduction in the main bioreactor cannot take place. Better OSA performance occurred at higher volatile solids loading to the external reactors. Effluent quality and sludge settleability were unaffected by SIR.

\section{Acknowledgements}

The authors wish to thank a large number of Sydney Water's personnel, particularly Stewart Ramsay and his team at the Wollongong Water Recycling Plant as well as Warwick Smith and his team at the Penrith Water Recycling Plant, for their logistic support. Financial support from TRILITY and Sydney Water is gratefully acknowledged. The $\mathrm{PhD}$ scholarship for Galilee U.

Semblante from the University of Wollongong is deeply appreciated.

\section{References}

Chiu, Y.-C., Chung, M.-S. 2003. Determination of optimal COD/nitrate ratio for biological denitrification. Inter Biodeter Biodegrad, 51(1), 43-49.

Chon, D.H., Rome, M., Kim, Y.M., Park, K.Y., Park, C. 2011. Investigation of the sludge reduction mechanism in the anaerobic side-stream reactor process using several control biological wastewater treatment processes. Water Res, 45(18), 6021-6029.

Chuang, S.H., Ouyang, C.F., Yuang, H.C., You, S.J. 1997. Effects of SRT and do on nutrient removal in a combined as-biofilm process. Water Sci Technol, 36(12), 19-27.

Chudoba, P., Morel, A., Capdeville, B. 1992. The case of both energetic uncoupling and metabolic selection of microorganisms in the OSA activated sludge system. Environmental Technology, 13(8), 761-770.

Clarke, R.M., Cummins, E. 2015. Evaluation of "Classic" and Emerging Contaminants Resulting from the Application of Biosolids to Agricultural Lands: A Review. Hum Ecol Risk Assess, 21(2), 492-513.

Coma, M., Rovira, S., Canals, J., Colprim, J. 2013. Minimization of sludge production by a sidestream reactor under anoxic conditions in a pilot plant. Bioresour Technol, 129(0), 229235.

Cortez, S., Teixeira, P., Oliveira, R., Mota, M. 2009. Effect of operating parameters on denitrification in an anoxic rotating biological contactor. Environ Technol, 30(13), 13811389.

Eaton, A.D., Clesceri, L.S., Greenberg, A.E. 2005. Standard Methods for Examination of Water \& Wastewater. 21 ed. American Public Health Association, Washington DC. 
Fang, F., Hu, H.-L., Qin, M.-M., Xue, Z.-X., Cao, J.-S., Hu, Z.-R. 2015. Effects of metabolic uncouplers on excess sludge reduction and microbial products of activated sludge. Bioresour Technol, 185, 1-6.

Feng, X.-C., Guo, W.-Q., Yang, S.-S., Zheng, H.-S., Du, J.-S., Wu, Q.-L., Ren, N.-Q. 2014. Possible causes of excess sludge reduction adding metabolic uncoupler, 3, 3', 4',5tetrachlorosalicylanilide (TCS), in sequence batch reactors. Bioresource Technology, 173, 96-103.

Foladori, P., Andreottola, G., Ziglio, G. 2010. Sludge reduction technologies in wastewater treatment plants. IWA Publishing, London.

Fytili, D., Zabaniotou, A. 2008. Utilization of sewage sludge in EU application of old and new methods-A review. Renewable and Sustainable Energy Reviews, 12(1), 116-140.

Goel, R.K., Noguera, D.R. 2006. Evaluation of sludge yield and phosphorus removal in a Cannibal solids reduction process. J Environ Eng, 132(10), 1331-1337.

Gómez, X., Cuetos, M.J., Cara, J., Morán, A., García, A.I. 2006. Anaerobic co-digestion of primary sludge and the fruit and vegetable fraction of the municipal solid wastes: Conditions for mixing and evaluation of the organic loading rate. Ren Energ, 31(12), 2017-2024.

Hao, X.D., Wang, Q.L., Zhu, J.Y., Van Loosdrecht, M.C.M. 2010. Microbiological Endogenous Processes in Biological Wastewater Treatment Systems. Crit Rev Env Sci Tech, 40(3), 239-265.

Khursheed, A., Sharma, M.K., Tyagi, V.K., Khan, A.A., Kazmi, A.A. 2015. Specific oxygen uptake rate gradient - Another possible cause of excess sludge reduction in oxic-settlinganaerobic (OSA) process. Chem Eng J, 281, 613-622.

Li, B., Wu, G. 2014. Effects of Sludge Retention Times on Nutrient Removal and Nitrous Oxide Emission in Biological Nutrient Removal Processes. Int J Env Res Pub Health, 11(4), 3553-3569.

Mahmood, T., Elliott, A. 2006. A review of secondary sludge reduction technologies for the pulp and paper industry. Water Res, 40(11), 2093-2112.

Mao, C., Feng, Y., Wang, X., Ren, G. 2015. Review on research achievements of biogas from anaerobic digestion. Ren Sust Energ Rev, 45, 540-555.

Mowla, D., Tran, H.N., Allen, D.G. 2013. A review of the properties of biosludge and its relevance to enhanced dewatering processes. Biomass Bioenerg, 58, 365-378.

Navaratna, D., Shu, L., Jegatheesan, V. 2014. Performance of a laboratory-scale membrane bioreactor consisting mixed liquor with aquatic worms under toxic conditions. Bioresour Technol, 155, 41-49.

Novak, J.T., Chon, D.H., Curtis, B.-A., Doyle, M. 2007. Biological Solids Reduction Using the Cannibal Process. Water Environ Res, 79(12), 2380-2386.

Ratanatamskul, C., Saleart, T. 2015. Effects of sludge recirculation rate and mixing time on performance of a prototype single-stage anaerobic digester for conversion of food wastes to biogas and energy recovery. Environ Sci Pollut Res, 1-7.

Saby, S., Djafer, M., Chen, G.H. 2003. Effect of low ORP in anoxic sludge zone on excess sludge production in oxic-settling-anoxic activated sludge process. Water Res, 37(1), 1120.

Semblante, G.U., Hai, F.I., Bustamante, H., Guevara, N., Price, W.E., Nghiem, L.D. 2015a. Effects of iron salt addition on biosolids reduction by oxic-settling-anoxic (OSA) process. International Biodeterioration \& Biodegradation, 104, 391-400. 
80

\section{1}

4

as

Semblante, G.U., Hai, F.I., Huang, X., Ball, A.S., Price, W.E., Nghiem, L.D. 2015b. Trace organic contaminants in biosolids: Impact of conventional wastewater and sludge processing technologies and emerging alternatives. J Hazard Mater, 300, 1-17.

Semblante, G.U., Hai, F.I., Ngo, H.H., Guo, W., You, S.-J., Price, W.E., Nghiem, L.D. 2014. Sludge cycling between aerobic, anoxic and anaerobic regimes to reduce sludge production during wastewater treatment: Performance, mechanisms, and implications. Bioresour Technol, 155(0), 395-409.

Sun, L., Randall, C.W., Novak, J.T. 2010. The Influence of Sludge Interchange Times on the Oxic-Settling-Anoxic Process. Water Environ Res, 82(6), 519-523.

Tchobanoglus, G., Burton, F., Stensel, H. 2003. Wastewater engineering: Treatment and reuse. American Water Works Association, New York.

Wang, Y., Xiao, Q., Liu, J., Yan, H., Wei, Y. 2015. Pilot-scale study of sludge pretreatment by microwave and sludge reduction based on lysis-cryptic growth. Bioresour Technol, 190, 140-147.

Yang, G., Zhang, G., Wang, H. 2015. Current state of sludge production, management, treatment and disposal in China. Water Res, 78, 60-73.

Yao, M., Li, Y., Zhang, Z.J., Wang, S.X. 2008. Comparative study on sludge production in SBBR system under OSA operational process. pp. 3368-3371.

Ye, F.X., Zhu, R.F., Li, Y. 2008. Effect of sludge retention time in sludge holding tank on excess sludge production in the oxic-settling-anoxic (OSA) activated sludge process. $J$ Chem Technol Biotechnol, 83(1), 109-114.

Zhou, Z., Qiao, W., Xing, C., Shen, X., Hu, D., Wang, L. 2014. A micro-aerobic hydrolysis process for sludge in situ reduction: Performance and microbial community structure. Bioresour Technol, 173, 452-456.

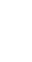

$\infty$

46

.

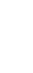

8

要

$\infty$

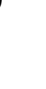




\section{List of Figures}

493 Figure 1. Schematic diagram of the control system composed of $\mathrm{SBR}_{\text {control }}$ and a single-pass

494 aerobic digester system (a) and the OSA system composed of SBR $_{O A A}$ and external

495 aerobic/anoxic and anoxic reactors $(\mathrm{b})$. The SIR between the anoxic reactor and $\mathrm{SBR}_{\mathrm{OSA}}\left(\mathrm{q}_{5}\right)$ was

496 adjusted to $0,11,16.5$, or $22 \%$. Consequently, the transfer rate of sludge from the anoxic reactor

497 to the aerobic/anoxic reactor $\left(\mathrm{q}_{4}\right)$ was $33,22,16.5$, or $11 \%$, respectively.

498 Figure 2. sCOD (a), ammonia (b), and orthophosphate (c) concentrations in $\mathrm{SBR}_{\text {control }}$ and

499 SBR $_{\mathrm{OSA}}$ at different SIR (0-22\%). The dotted line indicates the change of feed from settled to

500 unsettled sewage. Days 0-151 served as the reactor acclimatization period.

501 Figure 3. Influent COD and MLVSS of $\mathrm{SBR}_{\text {control }}$ and $\mathrm{SBR}_{\mathrm{OSA}}$ at different SIR (0-22\%). The

502 dotted line indicates the change of feed from settled to unsettled sewage. Days 0-151 served as

503 the reactor acclimatization period.

504 Figure 4. MLVSS/MLSS ratio of $\mathrm{SBR}_{\mathrm{OSA}}$ and external aerobic/anoxic and anoxic reactors at 505 different SIR (0-22\%). The dotted line indicates the change of feed from settled to unsettled 506 sewage. Days 0-151 served as the reactor acclimatization period.

507 Figure 5. Average phosphate (a), ammonia (b), nitrate (c), and nitrite (d) concentrations of the 508 feed sludge, supernatant of the aerobic/anoxic reactor, and supernatant of the anoxic reactor at 509 different SIR. Error bars indicate standard deviation of ' $n$ ' samples as follows: $n=4$ and 17 for 510 SIR of $22 \%$ and $11 \%$, respectively (settled sewage); $n=12,8$ and 9 , for SIR of 11,0 , and $11 \%$, 511 respectively (unsettled sewage). The dotted line indicates the change of feed from settled to 512 unsettled sewage. 


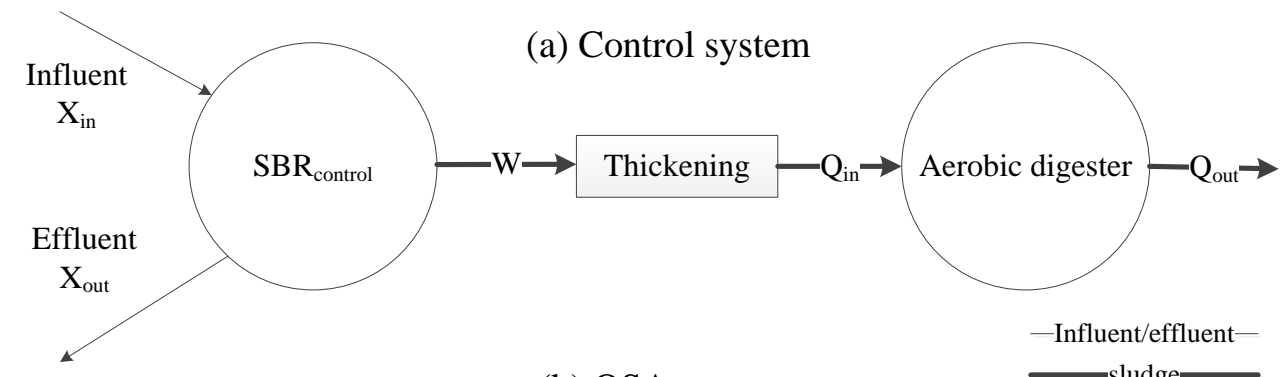

(b) OSA system

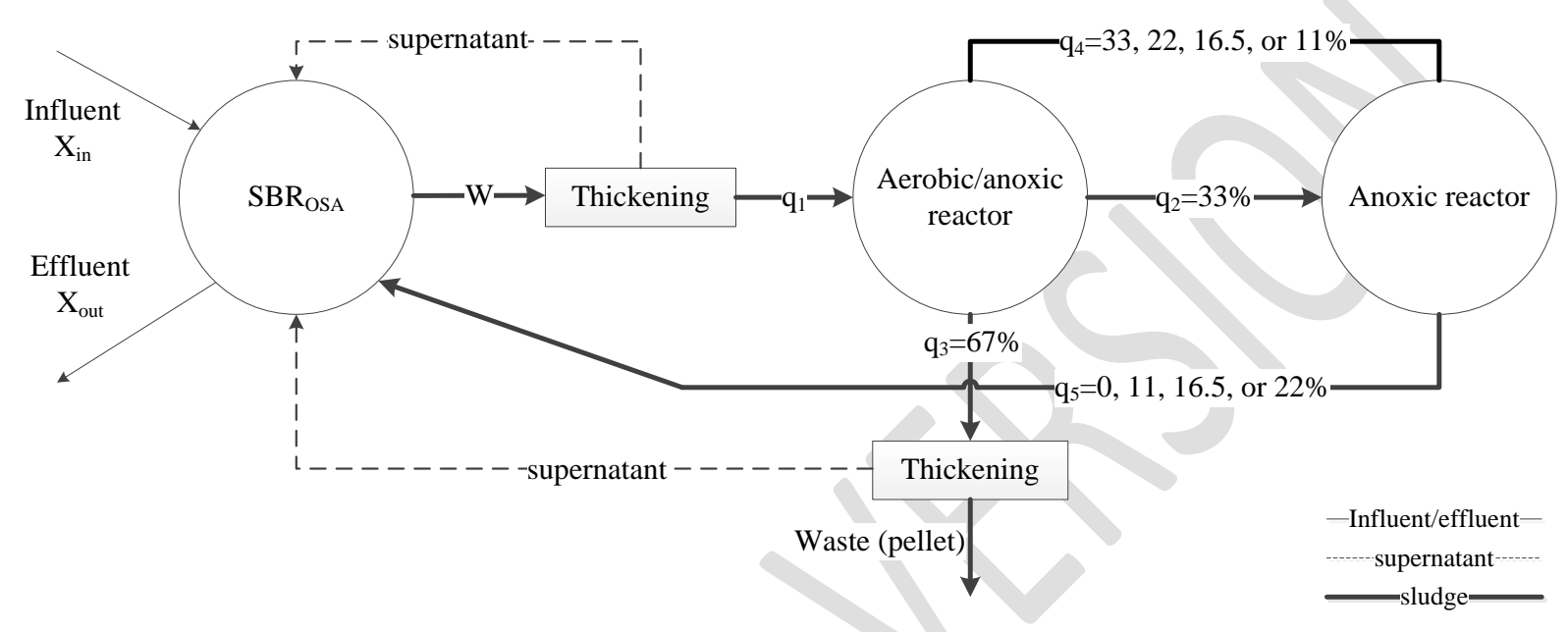



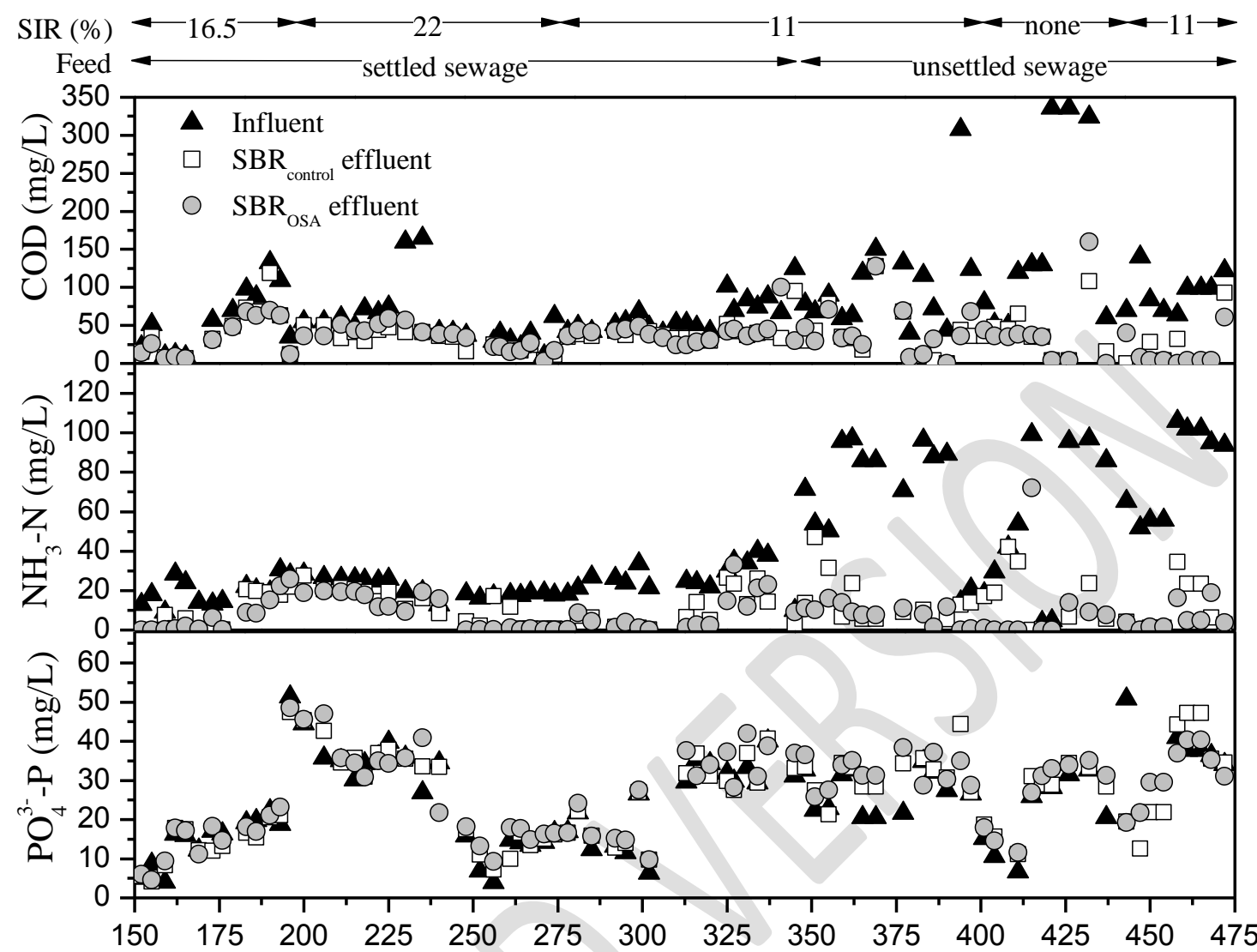

Time (day)

Figure 2 


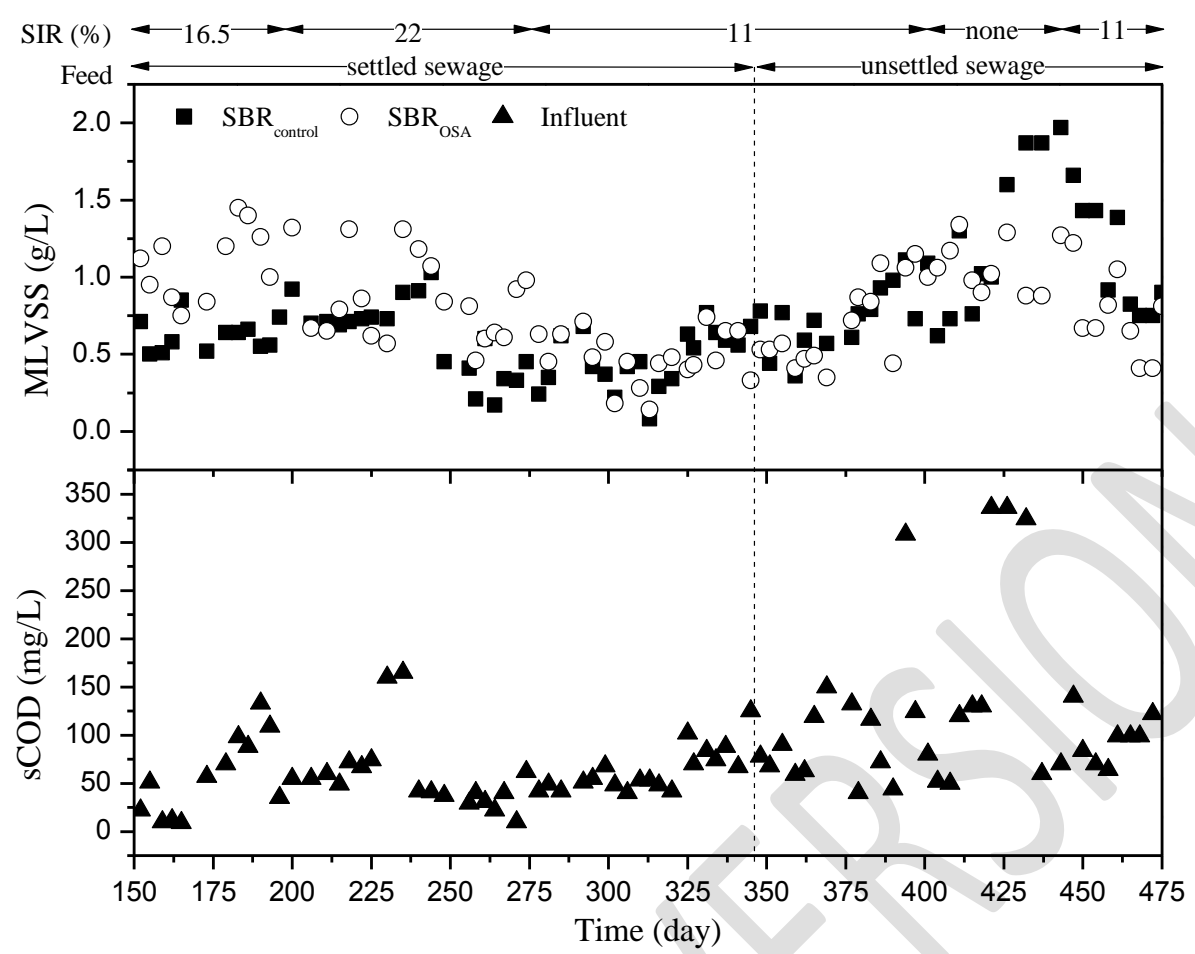

Figure 3

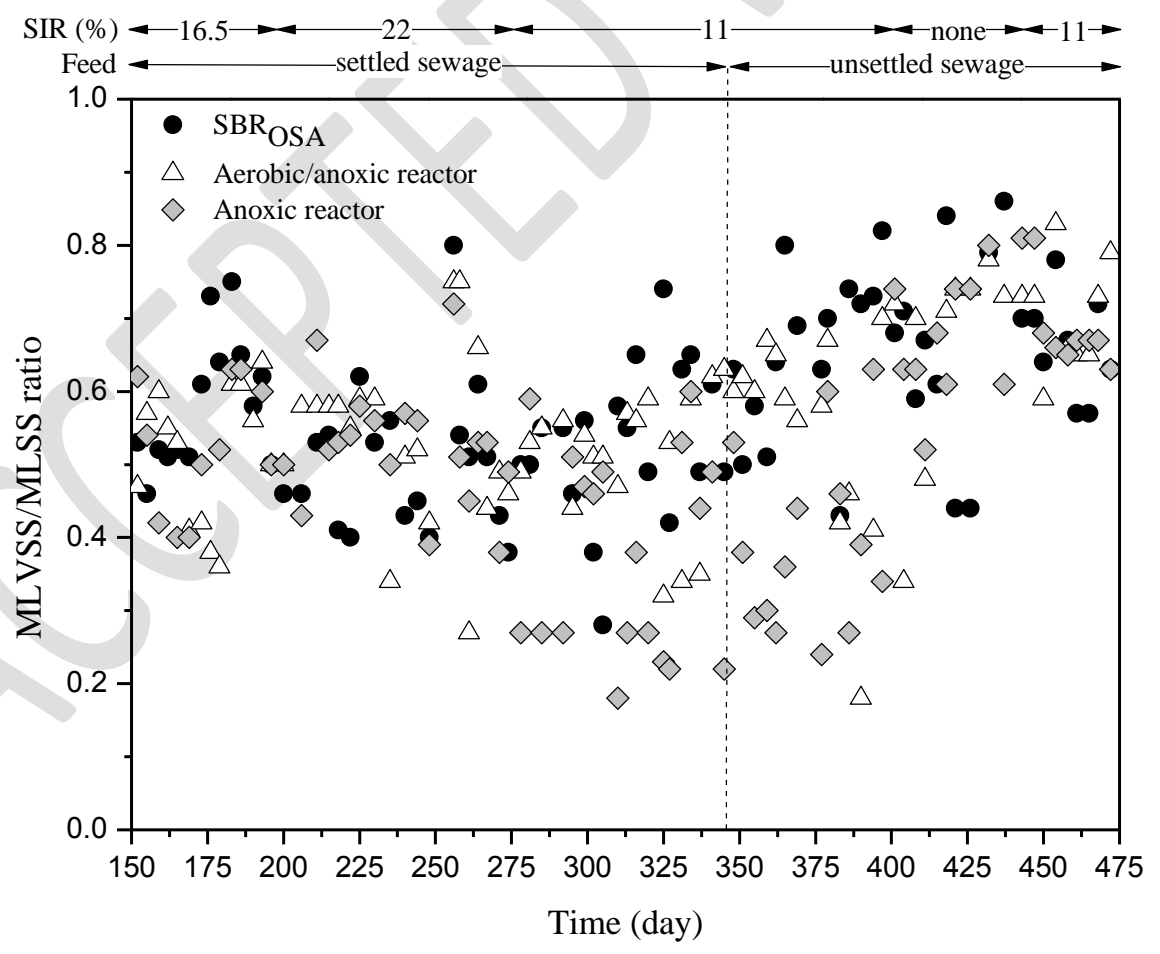

Figure 4 

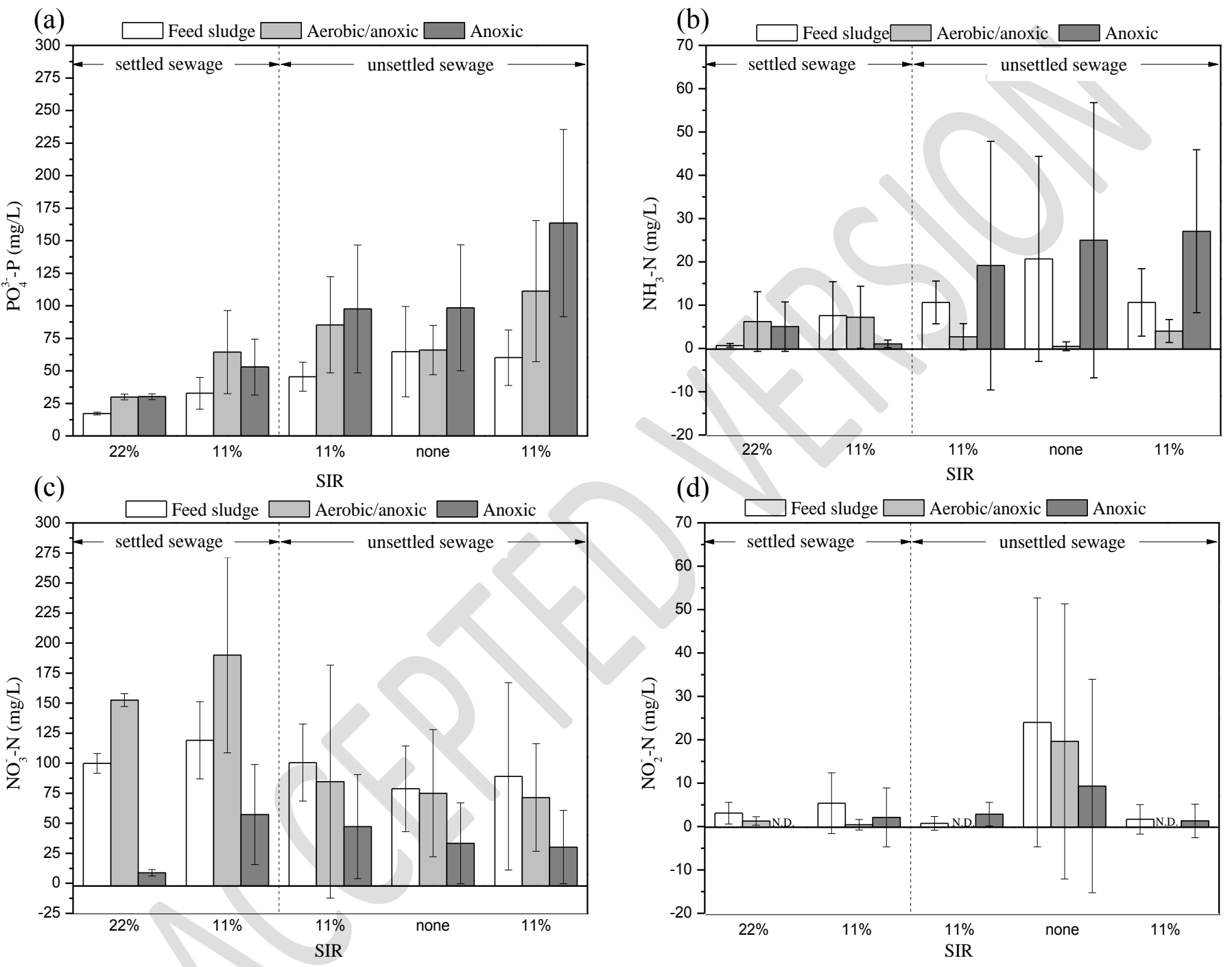

Figure 5 
538 Table 1. Average properties of settled and unsettled sewage

\begin{tabular}{ccc}
\hline Property & Settled sewage & Unsettled sewage \\
\hline sCOD $(\mathrm{mg} / \mathrm{L})$ & $60 \pm 32(\mathrm{n}=48)$ & $113 \pm 87(\mathrm{n}=33)$ \\
\hline $\mathrm{TOC}(\mathrm{mg} / \mathrm{L})$ & $50.6 \pm 21.9(\mathrm{n}=48)$ & $49.8 \pm 24.2(\mathrm{n}=33)$ \\
\hline $\mathrm{NH}_{3}-\mathrm{N}(\mathrm{mg} / \mathrm{L})$ & $31.2 \pm 7.5(\mathrm{n}=48)$ & $68.1 \pm 31.7(\mathrm{n}=33)$ \\
\hline $\mathrm{PO}_{4}{ }^{-3}-\mathrm{P}(\mathrm{mg} / \mathrm{L})$ & $26.0 \pm 12.0(\mathrm{n}=48)$ & $46.7 \pm 48.2(\mathrm{n}=33)$ \\
\hline $\mathrm{pH}$ & $5.9(\mathrm{n}=42)$ & $6.9(\mathrm{n}=32)$ \\
\hline $\mathrm{TSS}(\mathrm{g} / \mathrm{L})$ & $0.60 \pm 0.12(\mathrm{n}=48)$ & $0.67 \pm 0.08(\mathrm{n}=33)$ \\
\hline VSS $(\mathrm{g} / \mathrm{L})$ & $0.17 \pm 0.09(\mathrm{n}=48)$ & $0.19 \pm 0.07(\mathrm{n}=33)$ \\
\hline VSS/TSS & $0.28(\mathrm{n}=48)$ & $0.28(\mathrm{n}=48)$ \\
\hline
\end{tabular}

Table 2. Sludge yield ( $\left.\mathrm{Y}_{\mathrm{obs}}\right)$ of $\mathrm{SBR}_{\text {control }}$ and $\mathrm{SBR}_{\mathrm{OSA}}$ at different operation conditions (arranged chronologically). Days 0-151 served as the reactor acclimatization period.

\begin{tabular}{|c|c|c|c|c|c|c|c|c|}
\hline \multirow{2}{*}{$\begin{array}{l}\text { Time } \\
\text { (day) }\end{array}$} & \multirow{2}{*}{$\begin{array}{l}\text { Feed } \\
\text { type }\end{array}$} & \multirow{2}{*}{$\begin{array}{c}\text { Feed sCOD } \\
\text { concentration } \\
(\mathrm{mg} / \mathrm{L})\end{array}$} & \multirow{2}{*}{$\begin{array}{c}\text { SIR of } \\
\text { OSA }(\%)\end{array}$} & \multicolumn{4}{|c|}{ Sludge yield $\left(\mathrm{Y}_{\mathrm{obs}}\right)$} & \multirow[b]{2}{*}{$\begin{array}{c}\text { Reduction } \\
(\%)\end{array}$} \\
\hline & & & & $\mathrm{SBR}_{\text {control }}$ & $\mathrm{R}^{2}$ & $\mathrm{SBR}_{\mathrm{OSA}}$ & $\mathrm{R}^{2}$ & \\
\hline $152-195$ & $\begin{array}{l}\text { Settled } \\
\text { sewage }\end{array}$ & $\begin{array}{l}60 \pm 43 \\
(n=11) \\
\end{array}$ & 16.5 & 10.54 & 0.85 & 7.87 & 0.92 & 25 \\
\hline $196-274$ & $\begin{array}{l}\text { Settled } \\
\text { sewage }\end{array}$ & $\begin{array}{l}58 \pm 40 \\
(n=20)\end{array}$ & 22 & 3.50 & 0.85 & 4.01 & 0.93 & None \\
\hline $275-346$ & $\begin{array}{l}\text { Settled } \\
\text { sewage }\end{array}$ & $\begin{array}{l}59 \pm 18 \\
(\mathrm{n}=18)\end{array}$ & 11 & 1.54 & 0.93 & 0.73 & 0.78 & 53 \\
\hline $347-400$ & $\begin{array}{l}\text { Unsettled } \\
\text { sewage }\end{array}$ & $\begin{array}{c}105 \pm 68 \\
(n=14)\end{array}$ & 11 & 0.50 & 0.60 & 0.00 & 0.85 & $100^{\mathrm{b}}$ \\
\hline $401-441$ & $\begin{array}{c}\text { Unsettled } \\
\text { sewage }\end{array}$ & $\begin{array}{c}162 \pm 121 \\
(n=10)\end{array}$ & 0 & 0.14 & 0.70 & 0.14 & 0.78 & None \\
\hline $442-475$ & $\begin{array}{c}\text { Unsettled } \\
\text { sewage }\end{array}$ & $74 \pm 36(\mathrm{n}=9)^{\mathrm{a}}$ & 11 & 1.96 & 0.93 & 1.40 & 0.93 & 29 \\
\hline
\end{tabular}

${ }^{\mathrm{b}}$ No excess sludge yield 

William E. Price $^{c}$, and Long D. Nghiem ${ }^{\mathrm{a}}$

556 Engineering, University of Wollongong, Wollongong, NSW 2522, Australia ${ }^{\mathrm{b}}$ Sydney Water, Parramatta, NSW 2124, Australia

$564 *$ Corresponding author:

565 Email: faisal@uow.edu.au,Ph: +61 242213054

566

567

568

569

570

571 
572 Table S1. Summary of operation conditions

\begin{tabular}{ccc}
\hline Time (day) & Feed & SIR $(\%)$ \\
\hline $0-151$ & Settled sewage & Stabilisation period \\
\hline $152-195$ & Settled sewage & 16.5 \\
\hline $196-274$ & Settled sewage & 22 \\
\hline $275-346$ & Settled sewage & 11 \\
\hline $347-400$ & Unsettled sewage & 11 \\
\hline $401-441$ & Unsettled sewage & None (sludge interchange between SBR $\begin{array}{c}\text { OSA and external } \\
\text { reactors is suspended) }\end{array}$ \\
\hline $442-475$ & Unsettled sewage & 11 \\
\hline & &
\end{tabular}

573

574

575

576

577

578

579

580

581

582

583

584

585

586

587

588

589

590

591 
Table S2. Calculation of sludge yield

The MLVSS produced by $\operatorname{SBR}_{\text {control }}\left(P_{S B R \text { control }}\right)$ and $\operatorname{SBR}_{\mathrm{OSA}}\left(P_{S B R O S A}\right)$ at a given time interval were quantified using a mass balance of biomass and shown in Equation S.1 and S.2, respectively:

$$
\begin{array}{cr}
P_{S B R_{\text {control }}}=\Delta M L V S S_{S B R_{\text {control }}} \times V_{S B R_{\text {control }}} \times\left(V S S_{e 1} \times X_{\text {out }}+M L V S S_{S B R_{\text {control }}} \times W\right. & \text { Equation } \\
\left.-V S S_{i} \times X_{\text {in }}\right) \times \Delta t & \text { S.1 } \\
P_{S B R_{P S A}}=\Delta M L V S S_{S B R_{P S A}} \times V_{S B R_{P S A}}+\left(V S S_{e 2} \times X_{\text {out }}+M L V S S_{S B R_{P S A}} \times W-V S S_{i} \times X_{\text {in }}-\right. & \text { Equation } \\
\left.M L V S S_{A N X} \times q_{5}\right) \times \Delta t & \text { S.2 }
\end{array}
$$

wherein MLVSS $S_{S B R \text { control, SBROSA or } A N X}$ is the biomass concentration of the SBRs and the anoxic reactor, $V_{S B R \text { control or } S B R O S A}$ is the effective reactor volume, $V S S_{i}$ is the volatile suspended solids concentration of the influent, $V S S_{\text {e1 or } e_{2}}$ is volatile suspended solids concentration of the effluent, $X_{\text {in or out }}$ is flow rate of the influent or effluent, $W$ is the flow rate of sludge wasted from the SBRs, $q_{5}$ is the flow rate of sludge returned from the anoxic reactor to $S B R_{O S A}$ (Section 2.2), and $t$ is time. Notably, $V S S_{i}$ is deducted from the calculation of $P_{S B R c o n t r o l}$ and $P_{S B R O S A}$ to discount the significant amount of volatile solids carried by real wastewater (e.g. 0.1-0.5 g/L), and $M L V S S_{A N X}$ is deducted from the calculation of $P_{S B R O S A}$ to discount the biomass that was only recycled back to $S B R_{O S A}$ from the external anoxic reactor.

The $\mathrm{Y}_{\mathrm{obs}}$ of the control and OSA systems were determined. The synthesis of cells in the aerobic digester and OSA may occur even under limited substrate conditions when microorganisms consume products of cell lysis, so those reactors may also contribute to MLVSS production of the whole system. The MLVSS production of the control $\left(P_{\text {control }}\right)$ and OSA $\left(P_{O S A}\right)$ systems were calculated using Equations S.3 and S.4, respectively:

$$
\begin{array}{cr}
P_{\text {control }}=\Delta M L V S S_{S B R \text { control }} \times V_{S B R c o n t r o l}+\Delta M L V S S_{A E} \times V_{A E}+\left(V S S_{e 1} \times X_{\text {out }}+M L V S S_{A E} \times Q_{\text {out }}\right. & \text { Equation } \\
\left.-V S S_{i} \times X_{\text {in }}\right) \times \Delta t & \mathrm{~S} .3 \\
P_{O S A}=\Delta M L V S S_{S B R_{O S A}} \times V_{S B R_{O S A}}+\Delta M L V S S_{A E / A N X} \times V_{A E / A N X}+\Delta M L V S S_{A N X} \times V_{A N X}+ & \text { Equation } \\
\left(V S S_{e 2} \times X_{o u t}+M L V S S_{A E / A N X} \times q_{3}-V S S_{i} \times X_{\text {in }}\right) \times \Delta t & \mathrm{~S} .4
\end{array}
$$

wherein $M L V S S_{A E / A N X \text { or } A N X}$ is the biomass concentration of the aerobic/anoxic and anoxic reactors, $V_{A E, A E / A N X \text { or } A N X}$ is the effective digester or reactor volume, $Q_{\text {out }}$ is the flow rate of sludge wasted from the aerobic digester, and $q_{3}$ is flow rate of sludge wasted from the aerobic/anoxic reactor. Notably, the sludge interchanged within the external reactors and between $\mathrm{SBR}_{\mathrm{OSA}}$ and external reactors were retained in the system hence it is not necessary to deduct those sludge flows from the calculation of $P_{O S A}$.

The amount of substrate consumed $C$ by individual SBRs, and the control and OSA systems was calculated according to Equation S.5:

$$
C=\left(C O D_{i}-C O D_{e 1 o r e 2}\right) \times X_{\text {in }}
$$

wherein $\mathrm{COD}_{\mathrm{i}}$ and $\mathrm{COD}_{\mathrm{e} 1 / \mathrm{e} 2}$ are the soluble COD of the influent and effluent, respectively. 
$\Delta$ Influent $\square \mathrm{SBR}_{\text {control }}$ effluent $\bigcirc \mathrm{SBR}_{\mathrm{OSA}}$ effluent $-\square-\mathrm{SBR}_{\text {control }}$ removal $-\mathrm{O}-\mathrm{SBR}_{\mathrm{OSA}}$ removal

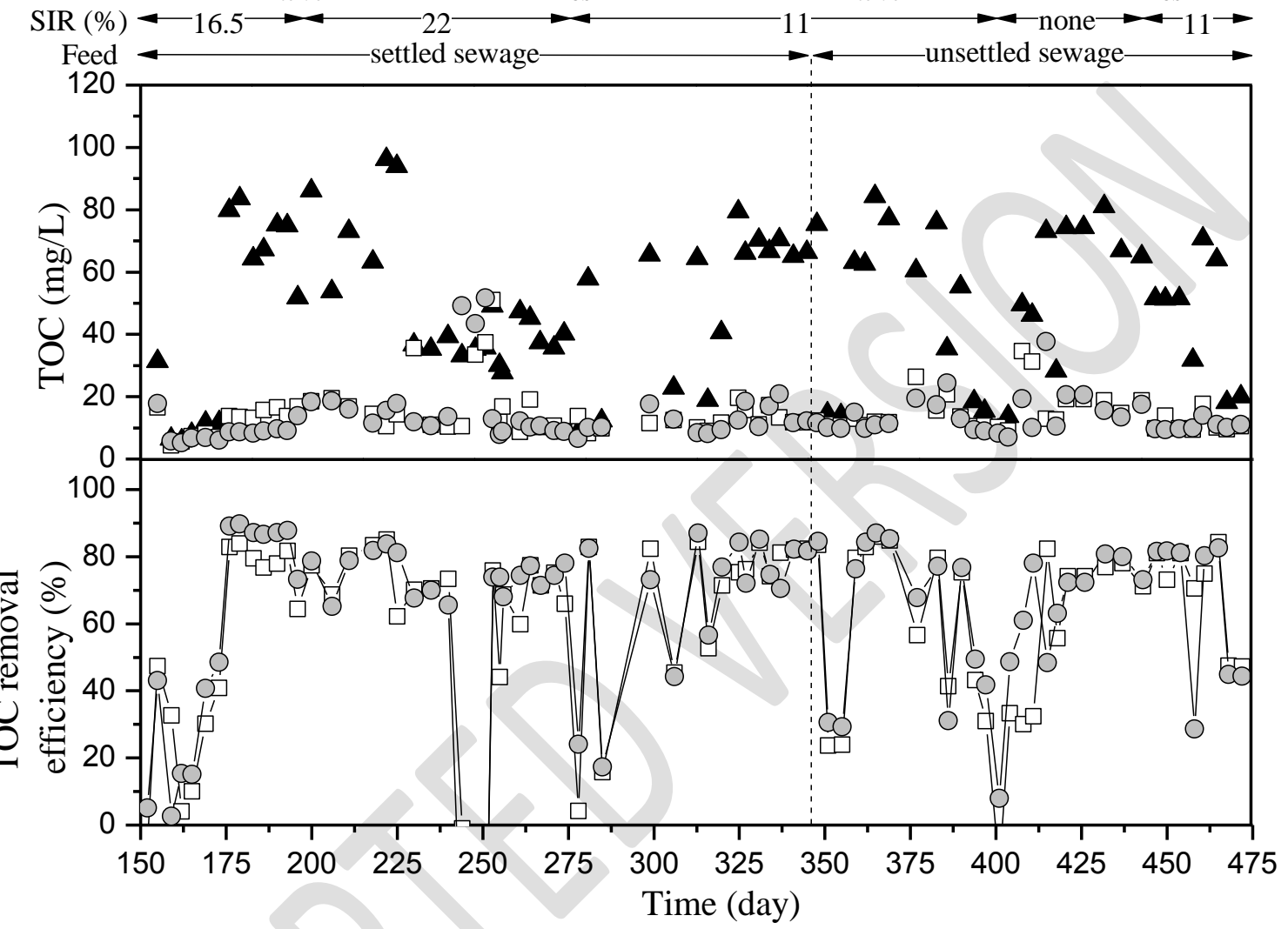

597 Figure S3. TOC concentration and removal efficiency of $\mathrm{SBR}_{\text {control }}$ and $\mathrm{SBR}_{\mathrm{OSA}}$ at different sludge interchange rates (0-22\%). The dotted line indicates the change of feed from settled to 


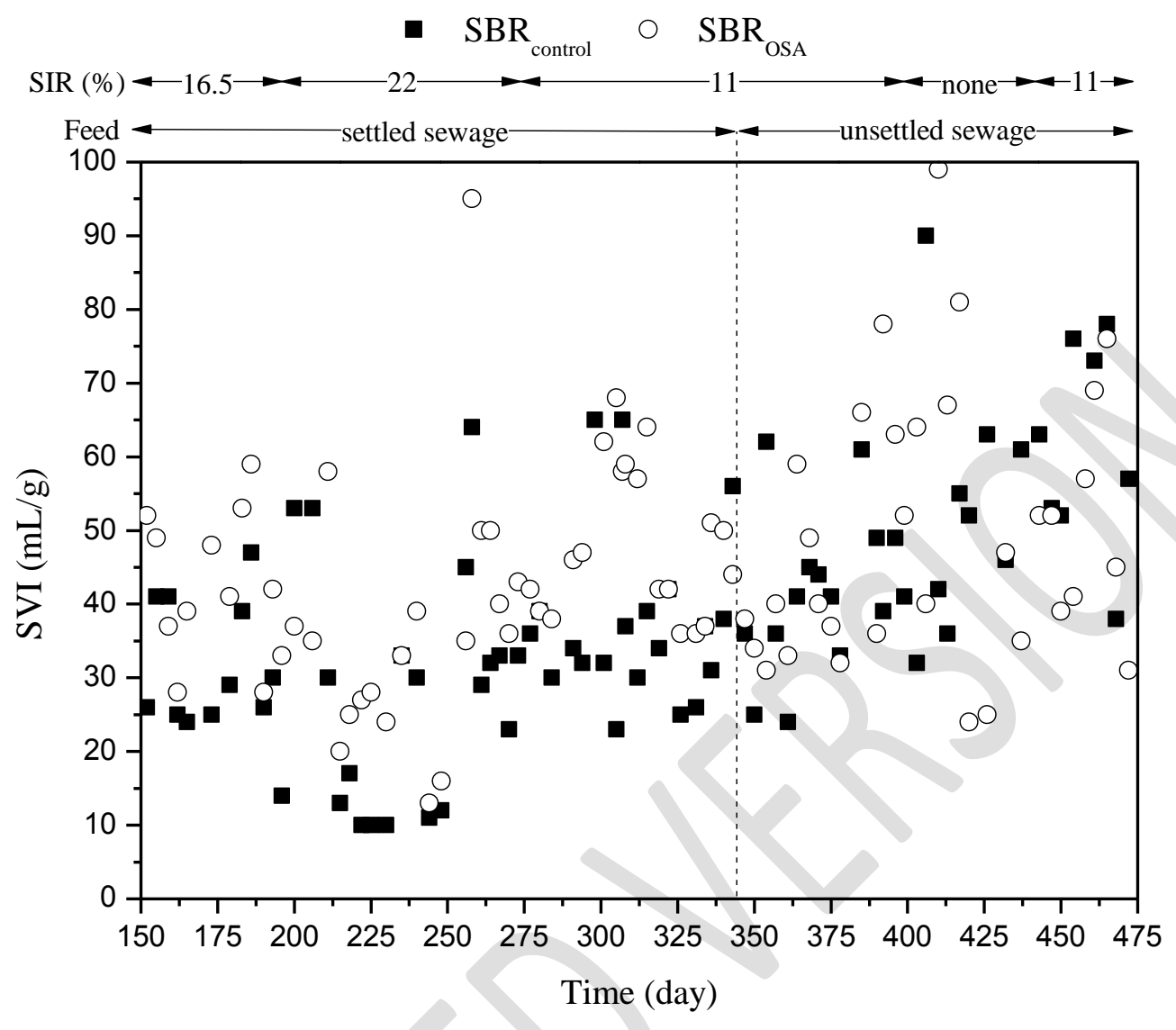

603

604 Figure S4. SVI of $\mathrm{SBR}_{\text {control }}$ and $\mathrm{SBR}_{\mathrm{OSA}}$ at different sludge interchange rates (0-22\%). The 605 dotted line indicates the change of feed from settled to unsettled sewage. Days 0-151 served as 606 the reactor acclimatization period. 

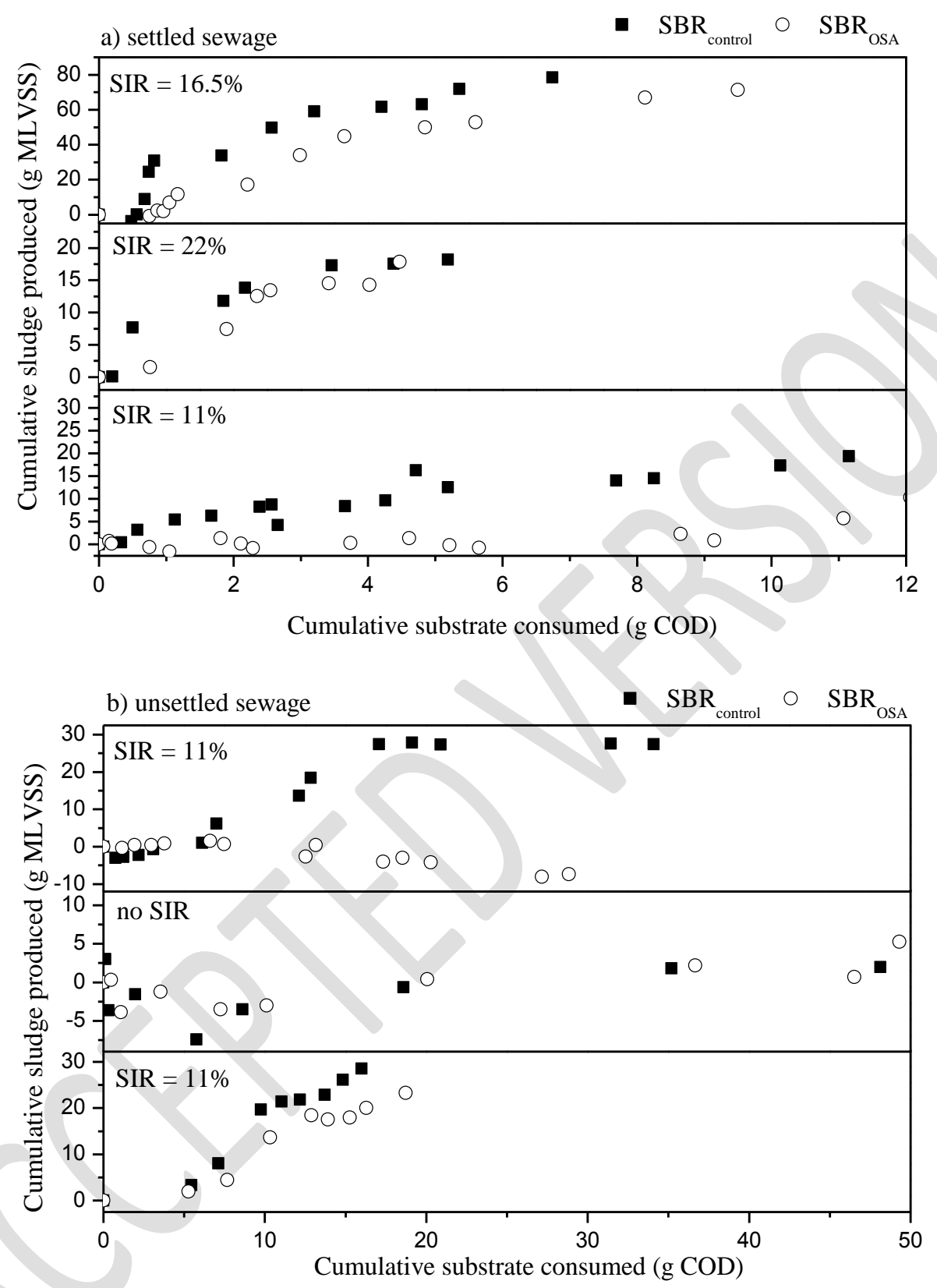

608 Figure S5. Sludge yield of $\mathrm{SBR}_{\text {control }}$ and $\mathrm{SBR}_{\mathrm{OSA}}$ at different sludge interchange rates (0-22\%) 
612 Table S6. Sludge yield ( $\left.\mathrm{Y}_{\mathrm{obs}}\right)$ of control (e.g., combined $\mathrm{SBR}_{\text {control }}$ and aerobic digester) and 613 OSA (e.g., combined $\mathrm{SBR}_{\mathrm{OSA}}$ and external aerobic/anoxic and anoxic reactors) systems at 614 different operation conditions

\begin{tabular}{cccccc}
\hline Feed & SIR of OSA (\%) & $\begin{array}{c}\text { Control } \\
\text { system }\end{array}$ & $\mathrm{R}^{2}$ & OSA & $\mathrm{R}^{2}$ \\
\hline $\begin{array}{c}\text { Settled } \\
\text { sewage }\end{array}$ & 16.5 & 8.75 & 0.87 & 6.69 & 0.96 \\
\hline $\begin{array}{c}\text { Settled } \\
\text { sewage }\end{array}$ & 22 & 0.96 & 0.65 & 1.95 & 0.57 \\
\hline $\begin{array}{c}\text { Settled } \\
\text { sewage }\end{array}$ & 11 & 1.23 & 0.88 & -0 & - \\
\hline $\begin{array}{c}\text { Unsettled } \\
\text { sewage }\end{array}$ & 11 & 1.06 & 0.75 & -0.58 & 0.92 \\
\hline $\begin{array}{c}\text { Unsettled } \\
\text { sewage }\end{array}$ & 11 & 1.92 & 0.90 & 1.31 & 0.92 \\
\hline
\end{tabular}

615

616

617 


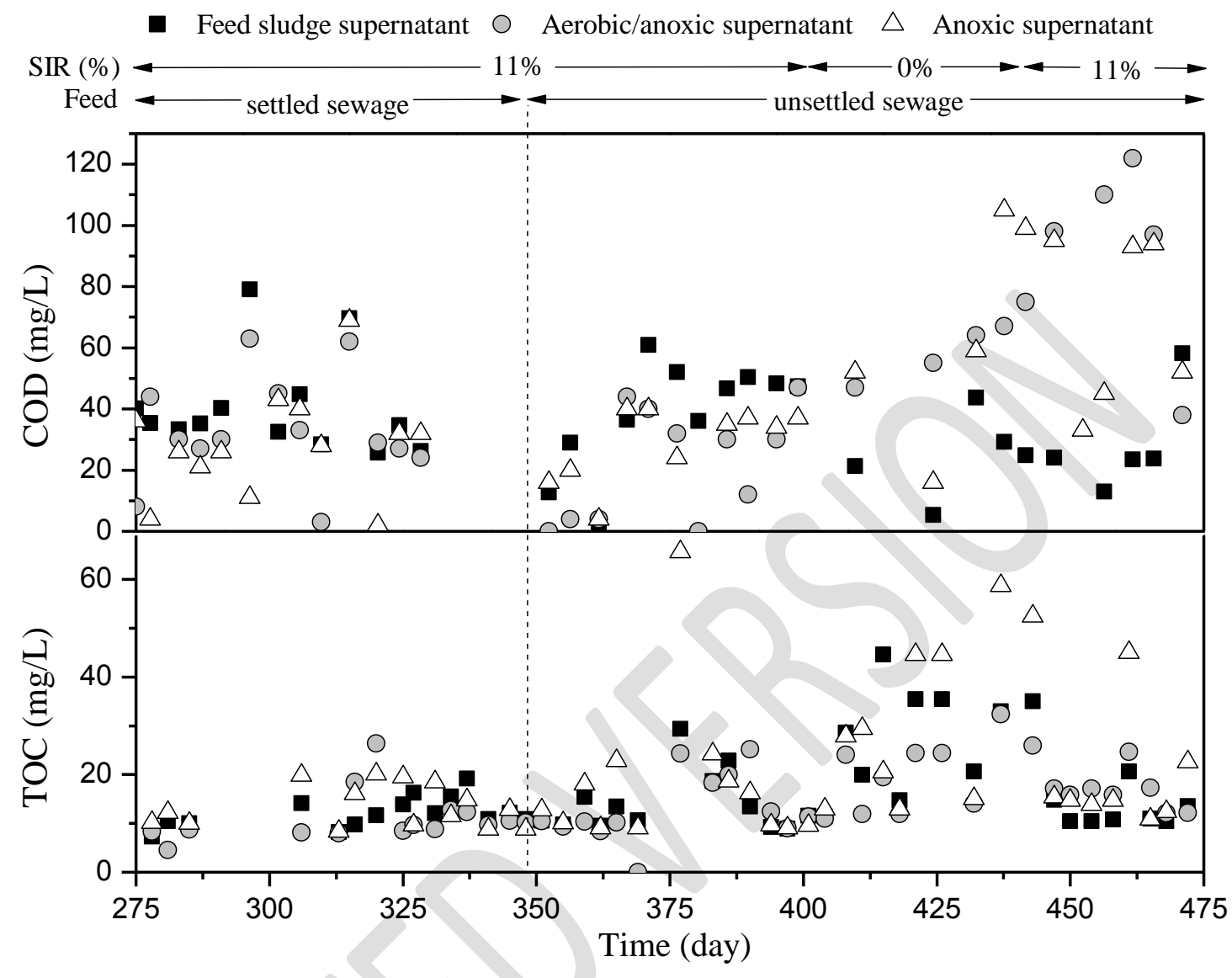

Figure S7. COD and TOC concentrations in the aerobic/anoxic and anoxic reactors. Feed sludge 


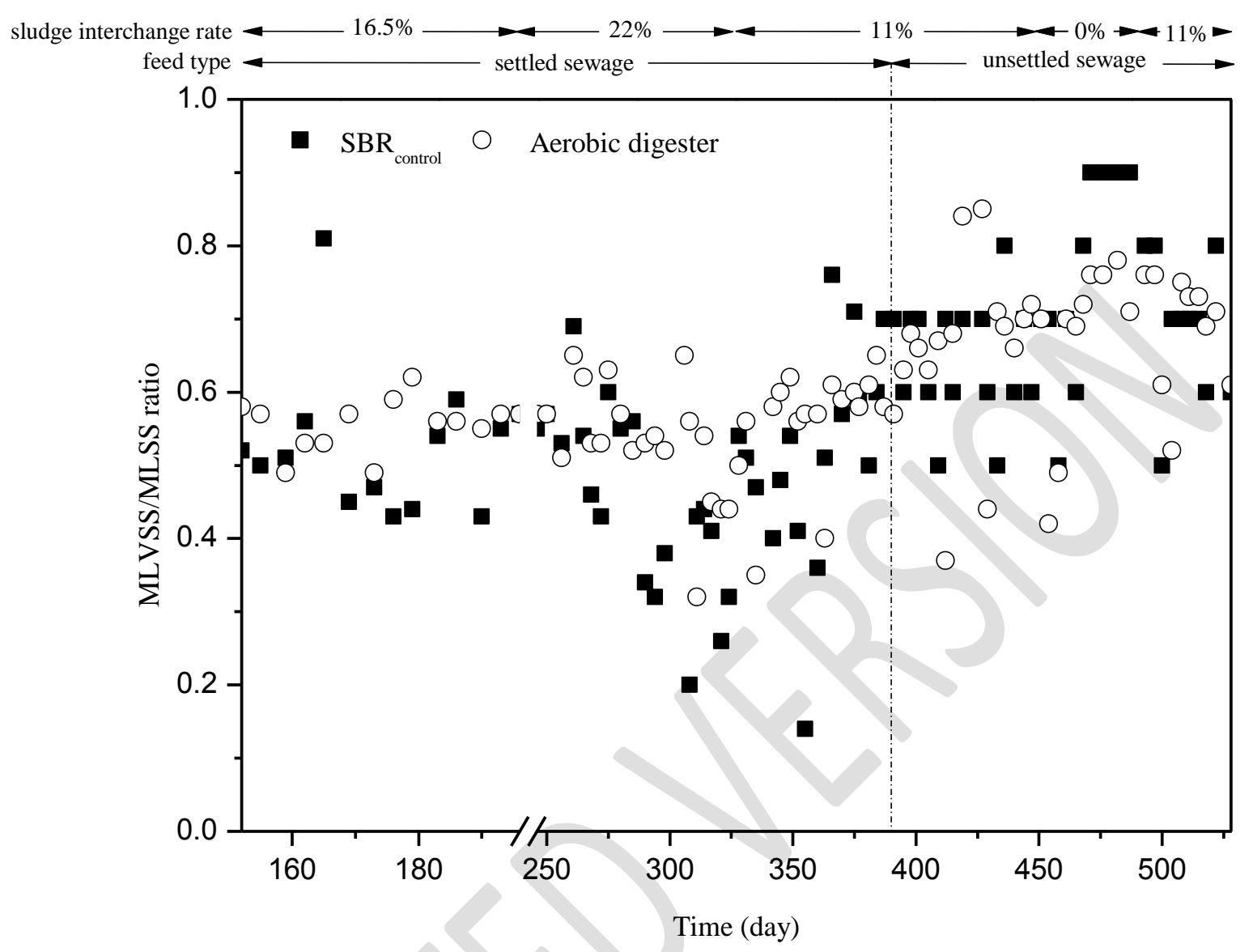

625

626

627 Figure S8. MLVSS/MLSS ratio of $\mathrm{SBR}_{\text {control }}$ and the aerobic digester. The dotted line indicates 628 the change of feed from settled to unsettled sewage. Days 0-151 served as the reactor 629 acclimatization period. 